\title{
Observations and trends on the intra-annual variation of the fish assemblages on two artificial reefs in Algarve coastal waters (southern Portugal)*
}

\author{
MIGUEL N. SANTOS, CARLOS C. MONTEIRO and GERARD LASSERRE \\ Instituto Nacional de Investigação Agrária e das Pescas (INIAP/IPIMAR), Centro Regional de Investigação Pesqueira do \\ Sul (CRIPSul), Avenida 5 de Outubro s/n, P-8700-305 Olhão, Portugal. E-mail: mnsantos@ cripsul.ipimar.pt
}

\begin{abstract}
SUMMARY: In 1990 two artificial reefs were deployed in southern Portuguese coastal waters, off Faro (FPR) and Olhão (OPR) respectively. In order to investigate the fish assemblages and their intra-annual variability, the two artificial reefs were monitored monthly by means of visual censuses from March 1994 to February 1995. Due to the complexity of the reefs, three strata were considered for fish counts. The two artificial reefs showed similar patterns in terms of residence status and spatial occupation. Most species recorded are characteristic of the infralittoral, the Sparidae family being the most represented. OPR, which is located closer to the main openings of the Ria Formosa lagoon, showed higher mean values than FPR in terms of: fish density $\left(2.01 \pm 0.74 \mathrm{fish} / \mathrm{m}^{3}\right)$, fish biomass $\left(123.6 \pm 77.4 \mathrm{~g} / \mathrm{m}^{3}\right)$ and number of species $(7.5)$. The effect of the juvenile fish migrations from the lagoon to the coastal waters was more evident at OPR. FPR showed a greater intraannual variation of the ecological indexes than OPR. The results show that artificial reefs that are equal in terms of complexity and size may aggregate different fish assemblages as a result of their isolation and the influence of both hydrological features (e.g. water temperature) and endogenous biological processes in the area (e.g. proximity of nursery grounds).
\end{abstract}

Keywords: artificial reefs, fish assemblages, intra-annual trends, Algarve (southern Portugal).

RESUMEN: OBSERVACIONES Y TENDENCIAS SOBRE LA VARIACIÓN INTRA-ANUAL DE LAS COMUNIDADES DE PECES DE DOS ARRECifes artificiales en aguas costeras Del Algarve (SUR DE Portugal). - En 1990 se fondearon dos arrecifes artificiales en aguas costeras del sur de Portugal, frente a Faro (FPR) y Olhão (OPR), respectivamente. A fin de investigar las comunidades de peces y su variabilidad intra-anual, los dos arrecifes artificiales fueron monitoreados mensualmente mediante censos visuales desde marzo 1994 a febrero 1995. Debido a la complejidad del arrecife, tres estratos fueron considerados para los contajes de peces. Los dos arrecifes artificiales mostraron pautas similares en términos de estatus de residencia y ocupación espacial. La mayor parte de especies censadas son características del infralitoral, siendo la família Sparidae la mejor representada. OPR, que está emplazado más cerca de las aperturas principales de la laguna de Ría Formosa, mostró valores medios superiores que FPR en términos de: densidad de peces $\left(2.01 \pm 0.74\right.$ peces $\left./ \mathrm{m}^{3}\right)$, biomasa de peces $\left(123.6 \pm 77.4 \mathrm{~g} / \mathrm{m}^{3}\right)$ y número de especies (7.5). El efecto de las migraciones de peces juveniles desde la laguna a las aguas costeras fue más evidente en OPR. FPR mostró una mayor variación intraanual de los índices ecológicos que OPR. Los resultados muestran que arrecifes artificales iguales en términos de complejidad y tamaño pueden agregar diferentes comunidades de peces como resultado de su aislamiento e influencia de características hidrológicas (p.e. temperatura del agua) y procesos biológicos endógenos en el área (p.e. proximidad de fondos nursería).

Palabras clave: arrecifes artificiales, comunidades de peces, tendencias intraanuales, Algarve (sur de Portugal).

\section{INTRODUCTION}

Artificial reefs are a popular enhancement technique in aquatic ecosystems (Stone et al., 1991). Dur-

*Received December 10, 2003. Accepted November 29, 2004. ing the last three decades they have been used worldwide for protecting juvenile populations and creating fishing grounds (Ardizzone et al., 1989; Spanier et al., 1989; Moreno et al., 1994; Gomez-Buckley and Haroun, 1994; Santos and Monteiro, 2001; Jensen, 2002). In 1990, the National Marine Research Insti- 
tute (IPIMAR) deployed the first artificial reef systems in Portuguese coastal waters. These were located off Ria Formosa lagoon (Algarve coast, southern Portugal), which is a highly productive system and a nursery for a great number of fish species that seasonally migrate to the inshore coastal waters, where they are exploited by the local fishing community (Monteiro et al., 1987, 1990). The artificial reef system included a protection reef that was intended to create shelters for the populations that migrate from the lagoon (Santos, 1997).

When artificial reefs are deployed, there is a need to qualitatively and quantitatively assess and monitor these habitats in order to determine whether the objectives are being met. Several studies on the fisheries (Santos and Monteiro, 1997, 1998) and ecological (Santos et al., 1995, 1996, 2002a) aspects of the artificial reefs of the south coast of Portugal have been presented. As part of the Algarve Artificial Reef Program, our goal was to describe and compare the observations and trends in the intra-annual variation of the fish assemblages of the first two protection reefs deployed in southern Portuguese waters.

\section{MATERIAL AND METHODS}

\section{Artificial reefs and study sites}

The five-year-old artificial reefs are located in two different areas of the Algarve coastal waters (south Portugal, Fig. 1). These artificial reefs were set off Ria Formosa lagoon, which is a nursery ground (Monteiro et al., 1987, 1990) for most local economically important species. The Faro Artificial Reef (FPR) is located 2.6-4.8 km off Faro on a sandy bottom, while the Olhão Artificial Reef (OPR) is 1.8-2.6 km off Olhão on a sandy-muddy bottom. Some scattered natural hard substrate was found near the FPR. The mean monthly sea surface water temperature variation during the period September 1995 to September 2004 is shown in Figure 2. A peak is observed in August and the minimum in February. During this period the sea surface water temperature ranged between 11.5 and $29^{\circ} \mathrm{C}$.

Each artificial reef consists of 735 small concrete cubic units $\left(2.7 \mathrm{~m}^{3}\right.$ per unit) divided into 21 groups, occupying a total area of 39 ha at depths of 17-22 m and 18-21 $\mathrm{m}$ at OPR and FPR respectively.

\section{Data collection}

Both artificial reef groups were visually censused from March 1994 to February 1995. Since we were interested comparing fish assemblages of the artificial reefs, divers carried out sampling between 11:00 and 13:00 $\mathrm{h}$ on the same day at both reefs to reduce bias due to daily migrations. In view of the tidal regime in the area and the fact that tides might affect visibility, all visual censuses were made during high tide. This procedure helped us to determine specific details about each reef and reduced the influence of: (i) visibility changes with the tides and (ii) the diel migrations that were described for these

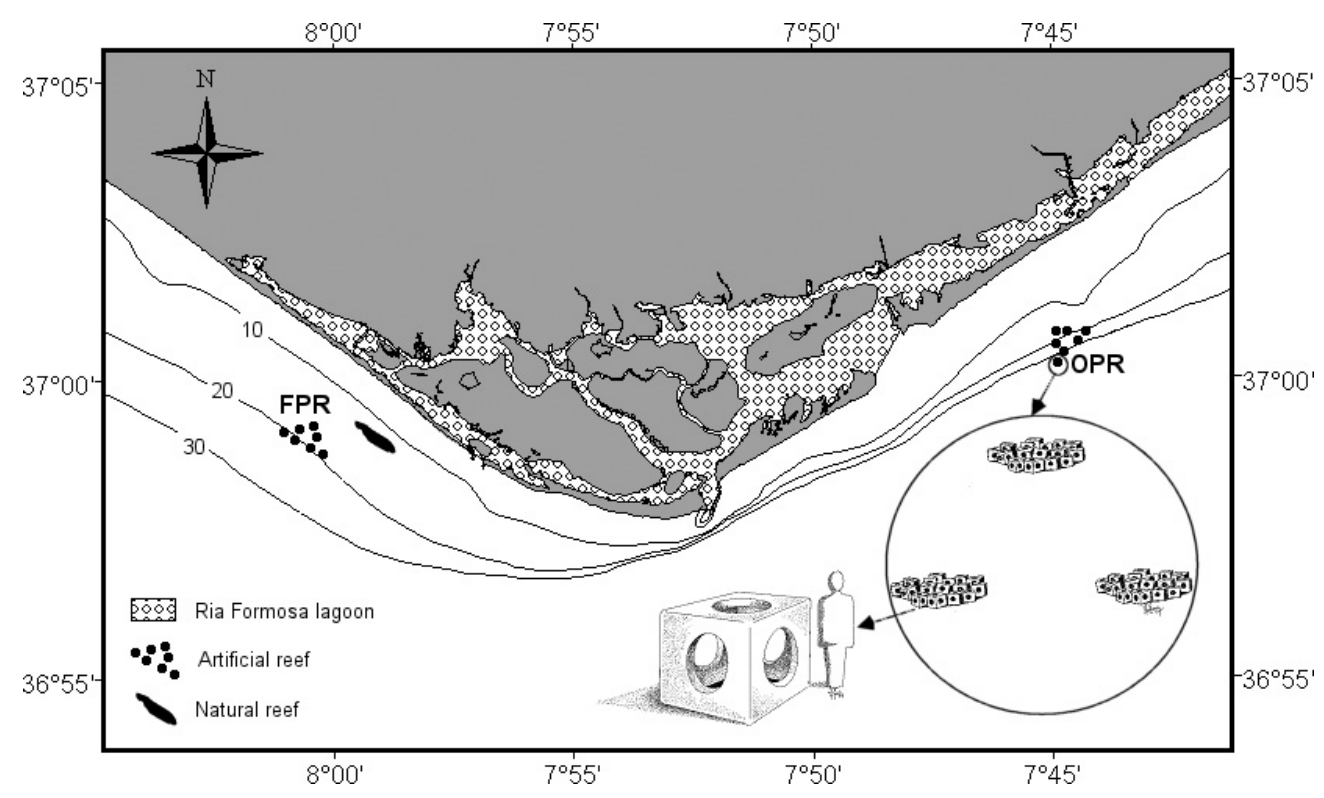

FIG. 1. - Location and scheme of the Faro (FPR) and Olhão (OPR) protection reefs on the Algarve coastal waters (southern Portugal). 


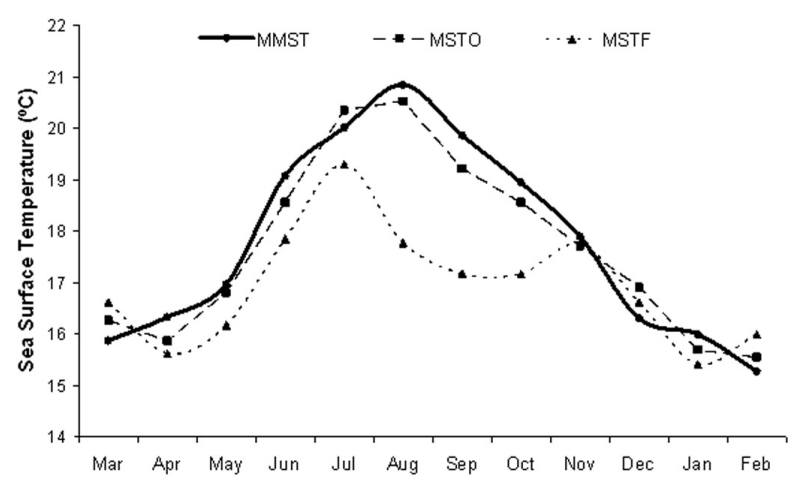

FIG. 2. - Mean monthly variation of sea surface water temperature $\left({ }^{\circ} \mathrm{C}\right)$ off Sta. Maria Cape (MMST) between 1994 and 2003 and at the study sites during the surveys (MSTO, Olhão protection reef; MSTF, Faro protection reef).

reefs by Santos et al. (2002a). The species-time random count method developed by Thompson and Schmidt (1977) and Jones and Thompson (1978) was used to determine the minimum time required to count the fish in the artificial reefs, following the method of Harmelin-Vivien et al. (1985). The stationary point count was then used to census the fish assemblages on the artificial reefs. This method, developed by Bohnsack and Bannerot (1986), is based on a census taken at randomly selected points, where the observer rotates around himself and counts the fish in the known cylinder (1.5 $\mathrm{m}$ height in our case). Due to the complexity of the reefs, three sampling points per stratum (bottom, middle and top of the reef) were used for fish counts. At each stratum divers recorded the fish species present within the area, along with their relative mean size and abundance, in a 6-minute interval (this minimum value was determined by the species-time random counts). The nomenclature adopted was that of Whitehead et al. (1986).

Density was calculated as the number of fish per $\mathrm{m}^{3}$ of water. The calculation of biomass density was made using: (1) the estimated average length of each species (for each sample), (2) the length-weight relationship (Santos et al., 2002b; Froese and Pauly, 2003; Borges et al., 2003) and (3) the estimated density of fish.

For each site the mean number of species and the mean Shannon-Weaver diversity index per sample were determined. Fish were assigned to spatial category, as suggested by Harmelin (1987) for fish from Mediterranean rocky bottoms:

- Category 1: highly mobile, gregarious, pelagic erratic species (e.g. Trachurus trachurus);

- Category 2: planktophagous and relatively sedentary species, living throughout the water column (e.g. Chromis chromis);
- Category 3: demersal mesophagous species, with medium-amplitude vertical movements and more-or-less important horizontal movements (e.g. Diplodus spp.);

- Category 4: demersal species, with limited vertical and considerable lateral movements (e.g. Mullus surmuletus);

- Category 5: sedentary demersal mesophagous species(e.g. Symphodus spp.);

- Category 6: highly-sedentary cryptic benthic species (e.g. Conger conger).

To show variability, the frequency of occurrence was calculated and expressed as a percentage of presence in all surveys. Four levels of frequency of occurrence were employed, as suggested by Harmelin (1987): level I, > 75\%; level II, 50\%-75\%; level III, 25\%-49.9\%; and level IV, 0\%-24.9\%. Finally, fish were categorized as resident, transient or occasional, according to their resident status as suggested by Bayle-Sempere et al. (1994).

\section{Statistical tests}

All statistical tests were carried out using SAS (1985) and/or STATISTICA (Statsoft, 1993). In order to compare the species-time random counts, a test of equality of two regression functions using a "dummy variable" (Neter et al., 1983) was made after log-transformation of data. Statistical comparisons were performed using the ANOVA/MANOVA (Scherrer, 1984). Levene's test was used to test equality of variances. Differences were determined with the Tukey HSD test. Since differences were found among the three strata of both reefs for most of the parameters, we treated them separately (see Table 1).

TABLE 1. - Results of the ANOVA for fish density, biomass density and mean number species (MNS) between strata within the two artificial reefs (FPR and OPR); ns, non significant; *, $\mathrm{p}<0.05$; $* *, \mathrm{p}<0.01$.

\begin{tabular}{lccccccc}
\hline & \multicolumn{9}{c}{ Fish density } & \multicolumn{3}{c}{ Biomass density } & \multicolumn{2}{c}{ MNS } \\
Month & Df & FPR & OPR & FPR & OPR & FPR & OPR \\
\hline March & 2 & $* *$ & $*$ & $* *$ & $* *$ & $* *$ & $* *$ \\
April & 2 & $* *$ & $\mathrm{~ns}$ & $* *$ & $*$ & $* *$ & $*$ \\
May & 2 & $\mathrm{~ns}$ & $*$ & $* *$ & $*$ & $* *$ & $* *$ \\
June & 2 & $* *$ & $*$ & $\mathrm{~ns}$ & $* *$ & $*$ & $* *$ \\
July & 2 & $* *$ & $* *$ & $*$ & $*$ & $* *$ & $\mathrm{~ns}$ \\
August & 2 & $* *$ & $* *$ & $* *$ & $* *$ & $* *$ & $* *$ \\
September & 2 & $* *$ & $*$ & $* *$ & $*$ & $* *$ & $* *$ \\
October & 2 & $* *$ & $* *$ & $* *$ & $*$ & $* *$ & $* *$ \\
November & 2 & $* *$ & $* *$ & $\mathrm{~ns}$ & $\mathrm{~ns}$ & $* *$ & $* *$ \\
December & 2 & $* *$ & $*$ & $* *$ & $* *$ & $* *$ & $*$ \\
January & 2 & $\mathrm{~ns}$ & $* *$ & $* *$ & $*$ & $*$ & $* *$ \\
February & 2 & $* *$ & $* *$ & $* *$ & $* *$ & $\mathrm{~ns}$ & $* *$ \\
& & & & & & & \\
\hline
\end{tabular}




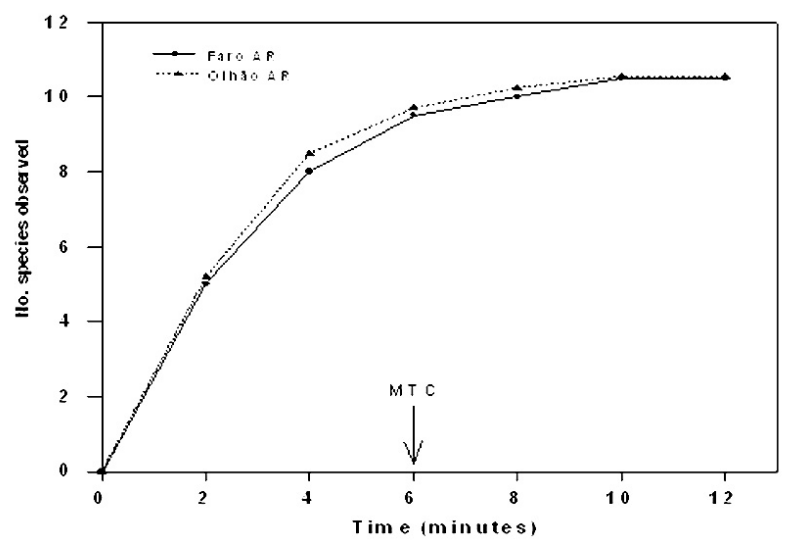

\section{RESULTS}

\section{Minimum time required for count}

The species-time random count allowed us to estimate the minimum time required for counting the fish in the reefs. For both artificial reefs 6 minutes was enough to see at least $90 \%$ of the species present (Fig. 3). The log-transformed curves were

FIG. 3. - Curves for determining the minimum time required for counting fish (MTC) at the Faro and Olhão artificial reefs on the Algarve coastal waters.

TABLE 2. - List of species recorded on the two artificial reefs and respective percentage of occurrence by stratum (T, top; M, middle; B, bottom) and reef (FPR, Faro protection reef; OPR, Olhão protection reef). RS, resident status: R, resident; T, transient; O, occasional. Cat, spatial occupation category (see text for category definitions).

\begin{tabular}{|c|c|c|c|c|c|c|c|c|c|c|}
\hline \multirow[b]{2}{*}{ Species } & \multirow[b]{2}{*}{$\mathrm{RS}$} & \multirow[b]{2}{*}{ Cat } & \multicolumn{4}{|c|}{ FPR } & \multicolumn{4}{|c|}{ OPR } \\
\hline & & & $\mathrm{T}$ & M & B & Reef & $\mathrm{T}$ & M & B & Reef \\
\hline \multicolumn{11}{|l|}{ SPARIDAE } \\
\hline Boops boops & $\mathrm{O}$ & 1 & 8 & 8 & & 8 & & & & \\
\hline Diplodus annularis & $\mathrm{R}$ & 3 & 67 & 67 & 61 & 100 & 92 & 100 & 100 & 100 \\
\hline Diplodus bellottii & $\mathrm{R}$ & 3 & 100 & 100 & 92 & 100 & 100 & 92 & 92 & 100 \\
\hline Diplodus vulgaris & $\mathrm{R}$ & 3 & 42 & 64 & 75 & 100 & 56 & 67 & 89 & 100 \\
\hline Diplodus cervinus & $\mathrm{T}$ & 3 & & 22 & 14 & 17 & & 25 & 14 & 33 \\
\hline Diplodus puntazzo & $\mathrm{R}$ & 3 & & 47 & 31 & 67 & & 44 & 44 & 58 \\
\hline Diplodus sargus & $\mathrm{R}$ & 3 & & 33 & 42 & 58 & & 17 & 25 & 25 \\
\hline Pagellus acarne & $\mathrm{T}$ & 1 & 8 & 8 & 8 & 8 & 39 & 25 & 8 & 33 \\
\hline Spondyliosoma cantharus & $\mathrm{T}$ & 3 & 33 & 22 & & 17 & 39 & 25 & & 42 \\
\hline \multicolumn{11}{|l|}{ BLENNIIDAE } \\
\hline Blennius ocellaris & $\mathrm{R}$ & 6 & 14 & & & 17 & 14 & & & 17 \\
\hline Parablennius spp. & $\mathrm{R}$ & 6 & 100 & 100 & 94 & 100 & 100 & 100 & 89 & 100 \\
\hline Parablennius rouxi & $\mathrm{R}$ & 6 & 100 & 100 & 94 & 100 & 100 & 100 & 89 & 100 \\
\hline APOGONIDAE & & & & & & & & & & \\
\hline Apogon imberbis & $\mathrm{R}$ & 6 & & & 25 & 25 & & & 14 & 17 \\
\hline \multicolumn{11}{|l|}{ LABRIDAE } \\
\hline Coris julis & $\mathrm{R}$ & 5 & 78 & 100 & 100 & 100 & 67 & 100 & 100 & 100 \\
\hline Symphodus bailloni & $\mathrm{T}$ & 5 & 14 & 42 & 33 & 50 & 14 & 33 & 36 & 42 \\
\hline Symphodus cinereus & $\mathrm{T}$ & 5 & 7 & 24 & 14 & 42 & 7 & 14 & 14 & 33 \\
\hline \multicolumn{11}{|l|}{ HAEMULIDAE } \\
\hline Plectorhinchus mediterraneus & $\mathrm{T}$ & 3 & & 6 & 8 & 8 & & 14 & 25 & 25 \\
\hline Pomadasys incisus & $\mathrm{T}$ & 3 & & 8 & 25 & 25 & & 14 & 25 & 33 \\
\hline \multicolumn{11}{|l|}{ SCORPAENIDAE } \\
\hline Scorpaena notata & $\mathrm{R}$ & 6 & 42 & 97 & 100 & 92 & 50 & 92 & 92 & 83 \\
\hline GADIDAE & & & & & & & & & & \\
\hline Trisopterus luscus & $\mathrm{R}$ & 3 & & 17 & 17 & 17 & & & & \\
\hline \multicolumn{11}{|l|}{ SERRÁNIDAE } \\
\hline Serranus cabrilla & $\mathrm{R}$ & 5 & 31 & 61 & 75 & 75 & 14 & 53 & 47 & 50 \\
\hline Serranus hepatus & $\mathrm{T}$ & 5 & & 8 & 8 & 8 & & 7 & 7 & 8 \\
\hline Serranus scriba & $\mathrm{T}$ & 5 & & & 8 & 8 & & & 7 & 8 \\
\hline \multicolumn{11}{|l|}{ CARANGIDAE } \\
\hline Trachurus trachurus & $\mathrm{O}$ & 1 & 8 & 8 & & 8 & 8 & & & 8 \\
\hline Trachurus picturatus & $\mathrm{O}$ & 1 & 8 & & & 8 & 8 & & & 8 \\
\hline \multicolumn{11}{|l|}{ SCOMBRIDAE } \\
\hline Scomber japonicus & $\mathrm{O}$ & 1 & 8 & & & 8 & 8 & & & 8 \\
\hline Scomber scombrus & $\mathrm{O}$ & 1 & 6 & & & 8 & 6 & & & 8 \\
\hline \multicolumn{11}{|l|}{ MULLIDAE } \\
\hline Mullus surmuletus & $\mathrm{O}$ & 4 & & & & & & & 6 & 8 \\
\hline \multicolumn{11}{|l|}{ MUGILIDAE } \\
\hline Liza aurata & $\mathrm{O}$ & 1 & & & & & 4 & 8 & 8 & 8 \\
\hline BALISTIDAE & & & & & & & & & & \\
\hline Balistes carolinensis & $\mathrm{O}$ & 3 & 6 & & & 8 & 8 & & & 8 \\
\hline \multicolumn{11}{|l|}{ CONGRIDAE } \\
\hline \multirow{2}{*}{\multicolumn{11}{|c|}{ MURAENIDAE }} \\
\hline & & & & & & & & & & \\
\hline \multirow{2}{*}{\multicolumn{11}{|c|}{$\begin{array}{l}\text { Muraena helena } \\
\text { TRACHINIDAE }\end{array}$}} \\
\hline & & & & & & & & & & \\
\hline Trachinus draco & $\mathrm{T}$ & 4 & & & 25 & 25 & & & 25 & 25 \\
\hline
\end{tabular}


TABLE 3. - List of most common species found in the different zones of the protection reefs (see text for zonation).

\begin{tabular}{|c|c|c|c|}
\hline \multicolumn{2}{|r|}{ UPPER ZONE } & \multicolumn{2}{|c|}{ TRANSITIONAL ZONE } \\
\hline & $\begin{array}{l}\text { Sardina pilchardus } \\
\text { Trachurus spp. } \\
\text { Scomber spp. } \\
\text { Boops boops }\end{array}$ & & $\begin{array}{l}\text { Trachurus trachurus } \\
\text { Pagellus acarne } \\
\text { Liza aurata } \\
\text { Trachinus draco } \\
\text { Boops boops } \\
\text { Diplodus bellottii } \\
\text { Diplodus vulgaris }\end{array}$ \\
\hline REEF ZONE & Peripheral sub-zone & $\begin{array}{l}\mathrm{IE} \\
\text { Inner sub-zone }\end{array}$ & Contact sub-zone \\
\hline $\begin{array}{l}\text { Mullus surmuletus } \\
\text { Trachinus draco }\end{array}$ & $\begin{array}{l}\text { Coris julis } \\
\text { Symphodus spp. } \\
\text { Serranus spp. } \\
\text { Spondyliosoma cantharus } \\
\text { Diplodus annularis } \\
\text { Diplodus bellottii } \\
\text { Diplodus vulgaris } \\
\text { Pagellus acarne } \\
\text { Balistes carolinensis }\end{array}$ & $\begin{array}{l}\text { Diplodus spp. } \\
\text { Plectorhinchus mediterraneus } \\
\text { Pomadasys incisus } \\
\text { Trisopterus luscus } \\
\text { Serranus spp. } \\
\text { Apogon imberbis } \\
\text { Coris julis } \\
\text { Symphodus spp. }\end{array}$ & $\begin{array}{l}\text { Conger conger } \\
\text { Muraena helena } \\
\text { Scorpaena notata } \\
\text { Blennius ocellaris } \\
\text { Parablennius spp. } \\
\text { Scorpaena notata }\end{array}$ \\
\hline
\end{tabular}

similar and not significantly different in slope $(\mathrm{p}=0.7048)$ or intercepts $(\mathrm{p}=0.7998)$.

\section{Community composition}

During the study period we found 33 fish species belonging to 16 families (Table 2). Among these, $70 \%$ were economically valuable. The Sparidae Family was the best represented ( 9 species), followed by the Serranidae, Labridae and Bleniidae (3 species each) and Haemulidae, Carangidae and Scombridae (2 species each). The rest of the families were represented by only one species each. At FPR, 31 out of the 33 species were recorded, while 30 were present at OPR. The total species richness increased from the top to the bottom of the reef.

\section{Residence status and spatial occupation}

The two artificial reefs showed similar patterns in terms of residence status and spatial occupation (see Table 2). Most of the species recorded were considered resident (45\%), with 10 classified as transient (30\%) and 8 as occasional (25\%). Eleven species belong to the third spatial occupation category, 7 to the sixth and first, 6 to the fifth and 2 to the fourth. The third category consisted mainly of sea breams (e.g. mostly Diplodus spp.), while wrasses (Coris julis and Symphodus spp.), blennies (Blennius ocellaris and Parablennius spp.) and combers (Serranus spp.) were characteristic of the fifth and sixth categories. According to the four lev- els of the species occurrence index most species were very common, followed respectively by rare, common and uncommon species.

The following description of different reef zones was based entirely on our observations while diving. This zonation has the reefs as the object of classification, rather than the species, as occurs in the usual classifications used to describe the resident status and spatial occupation of fish assemblages. Following the criteria adopted by Charbonnel (1990), we identified three major zones (Table 3):

The upper zone, which corresponds to the upper layer of the water column ( $5 \mathrm{~m}$ above the reef). In this zone we found mostly species that may be attracted to the reef by thigmotaxis. These included species belonging mainly to categories 1 and 2 .

The transitional zone, corresponding to a vast horizontal area around the reef (beginning $5 \mathrm{~m}$ from the reef edge). Species belonging to categories 1, 3 and 4 were particularly characteristic of this zone.

3) The reef zone, which corresponds to a zone occupied by the stable reef fish assemblages. This zone has a spherical shape, its border being an imaginary line $5 \mathrm{~m}$ from the reef. Within this zone, we distinguished four sub-zones:

i) The bottom border sub-zone, a narrow, circular area around the modules (within 1.5 to $5 \mathrm{~m}$ from the reef) and close to the bottom, characterised by the presence of benthic species.

ii) The peripheral sub-zone, surrounding the reef (within 0 to $1.5 \mathrm{~m}$ from the reef) and characterised by the presence of wrasses, combers and some seabreams. 

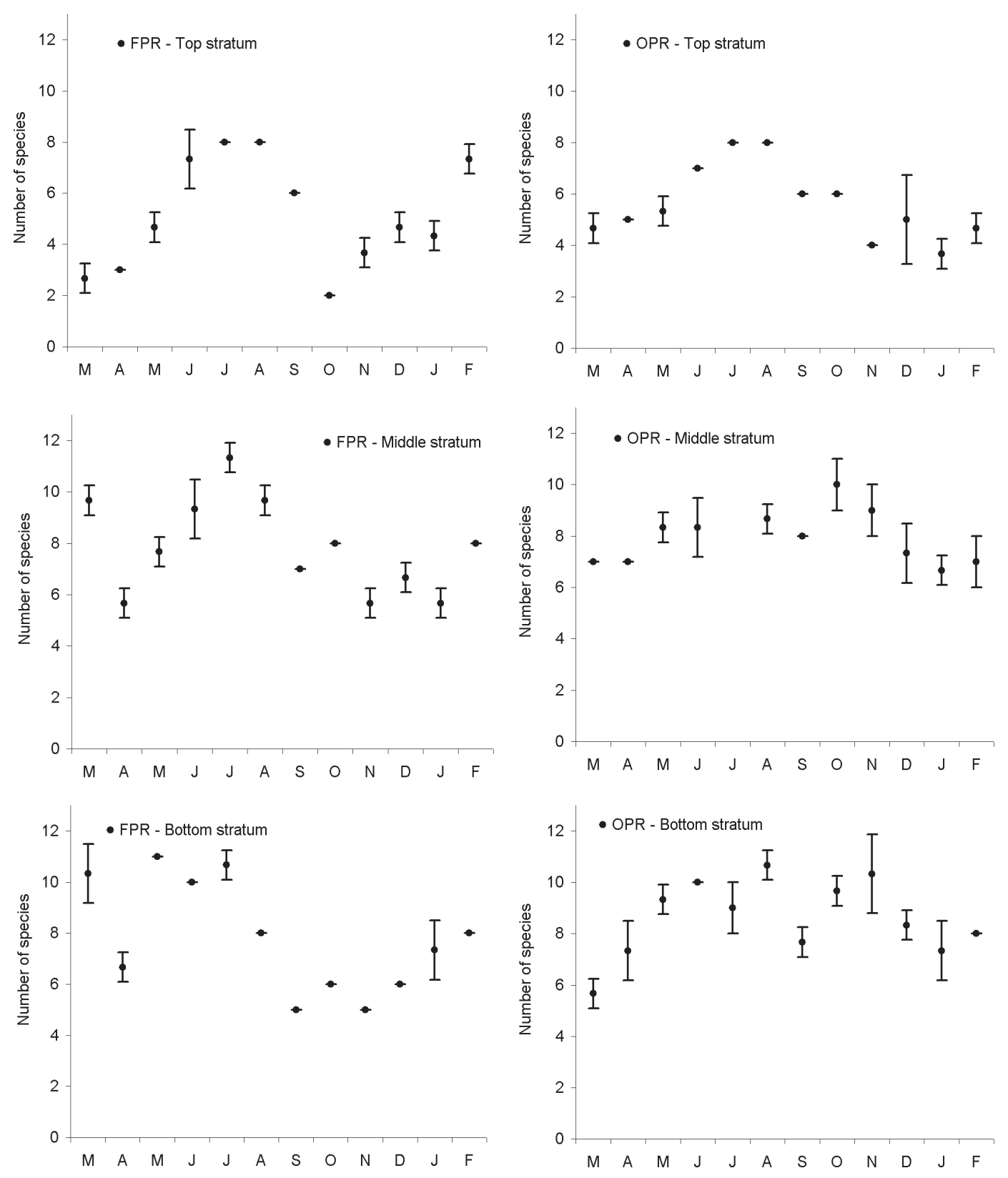

FIG. 4. - Mean number of species and standard deviation per stratum at the Faro protection reef (FPR) and the Olhão protection reef (OPR).

iii) The inner sub-zone, corresponding to an area inside the reef, occupied by those species that use the reef as a shelter.

iv) The contact sub-zone, occupied by benthic species living in physical contact with the modules.

\section{Mean species richness and mean species diversity}

The mean number of species at the different strata varied significantly during the year both within the artificial reefs and between the two sites (Fig. 4,
Table 4). The mean number of species at the top stratum varied from 2.0 to 8.0 at FPR and from 3.7 to 8.0 at OPR. The lowest values were recorded in October and January and the highest values from July to August at FPR and OPR respectively. For the middle stratum, the corresponding values for FPR and OPR ranged from 5.7 to 11.3 and 6.7 to 11.7. At FPR the lowest values occurred in April, November and January, while at OPR the minimum was recorded in March. The highest records were found in July and September at FPR and OPR respective1y. At the bottom stratum the mean number of 
TABLE 4. - Results of the ANOVA and MANOVA for fish density, biomass density and mean number of species (MNS) within and between the two artificial reefs. Df, degrees of freedom; ns, non significant; *, $\mathrm{p}<0.05 ; * *, \mathrm{p}<0.01$.

\begin{tabular}{|c|c|c|c|c|}
\hline \multicolumn{5}{|c|}{ FARO PROTECTION REEF } \\
\hline STRATUM & Df & Fish density & Biomass density & MNS \\
\hline Top & 11 & $* *$ & $* *$ & $* *$ \\
\hline Middle & 11 & $* *$ & $* *$ & $* *$ \\
\hline Bottom & 11 & $* *$ & $* *$ & $* *$ \\
\hline \multicolumn{5}{|c|}{ OLHÃO PROTECTION REEF } \\
\hline STRATUM & Df & Fish density & Biomass density & MNS \\
\hline Top & 11 & $* *$ & $* *$ & $* *$ \\
\hline Middle & 11 & $* *$ & $* *$ & $* *$ \\
\hline Bottom & 11 & $* *$ & $* *$ & $* *$ \\
\hline \multicolumn{5}{|c|}{ ENTIRE REEF } \\
\hline & Df & Fish density & Biomass density & MNS \\
\hline FPR vs OPR & 1 & $* *$ & $* *$ & $*$ \\
\hline \multirow[t]{2}{*}{ STRATUM: } & \multicolumn{4}{|c|}{ Top } \\
\hline & Df & Fish density & Biomass density & MNS \\
\hline Local & 1 & $* *$ & $* *$ & $* *$ \\
\hline Month & 11 & $* *$ & $* *$ & $* *$ \\
\hline Local x Month & 11 & $* *$ & $* *$ & $* *$ \\
\hline \multirow[t]{2}{*}{ STRATUM: } & \multicolumn{4}{|c|}{ Middle } \\
\hline & Df & Fish density & Biomass density & MNS \\
\hline Local & 1 & $* *$ & $* *$ & $*$ \\
\hline Month & 11 & $* *$ & $* *$ & $* *$ \\
\hline Local x Month & 11 & $* *$ & $* *$ & $* *$ \\
\hline \multirow[t]{2}{*}{ STRATUM: } & \multicolumn{4}{|c|}{ Bottom } \\
\hline & Df & Fish density & Biomass density & MNS \\
\hline Local & 1 & $* *$ & $* *$ & $* *$ \\
\hline Month & 11 & $* *$ & $* *$ & $* *$ \\
\hline Local x Month & 11 & $* *$ & $* *$ & $* *$ \\
\hline
\end{tabular}

species varied from 5.0 to 11.0 at FPR and from 5.7 to 10.7 at OPR. The lowest values were recorded in September and November at FPR and in March at OPR, while the highest were found in May and August. Considering the entire reef, different patterns in the annual variation of the mean number of species between the two artificial reefs were found (Table 4). The mean species richness at OPR was 7.5, which was higher than that at FPR (6.9). The greatest difference were observed between July and the winter months. At FPR we found two peaks corresponding to July and February, while at OPR there was only one in July (Fig. 4). However, the intraannual variability was higher at FPR (Table 5).

\section{Fish and biomass densities}

In terms of fish density we found significant differences between the two reefs (Table 4). The mean values found at OPR were 1.35 times higher than those at FPR (Table 5). However, the two reefs showed a similar variation during the year, reaching a maximum in summer (July and August respectively at FPR and OPR), decreasing until winter (lowest in January) and then increasing again. In terms of fish density among the stratum, significant differences were found both within and between the artificial reefs, with higher values at OPR (Fig. 5, Table 4). However, the different strata showed similar annual patterns, with the highest values in summer and the lowest in winter. In the top stratum the mean fish density ranged from 0.73 to $3.11 \mathrm{fish} / \mathrm{m}^{3}$ and 0.96 to $4.67 \mathrm{fish} / \mathrm{m}^{3}$ at FPR and OPR respectively. The mean fish density in the middle stratum of the FPR ranged from 0.95

TABLE 5. - Results of the monthly censuses in terms of the mean fish density (No. fish $\left./ \mathrm{m}^{3}\right)$, mean biomass density $\left(\mathrm{g} / \mathrm{m}^{3}\right)$ and mean number species (MNS) at the two artificial reefs. StD is the standard deviation.

\begin{tabular}{|c|c|c|c|c|c|c|}
\hline Month & fish dens. & $\begin{array}{c}\text { Faro protection reef } \\
\text { biom. dens. }\end{array}$ & MNS & fish dens. & $\begin{array}{l}\text { Olhão protection reef } \\
\text { biom. dens. }\end{array}$ & MNS \\
\hline March & 1.15 & 64.09 & 7.56 & 1.25 & 54.59 & 5.78 \\
\hline April & 1.36 & 68.11 & 5.11 & 1.47 & 84.38 & 6.44 \\
\hline May & 1.65 & 93.86 & 7.78 & 1.91 & 117.41 & 7.67 \\
\hline June & 2.10 & 101.46 & 8.89 & 2.19 & 168.69 & 8.44 \\
\hline July & 2.93 & 142.85 & 10.00 & 3.15 & 219.71 & 9.56 \\
\hline August & 2.14 & 119.51 & 8.56 & 3.38 & 233.28 & 9.11 \\
\hline September & 1.70 & 118.01 & 6.00 & 2.21 & 169.05 & 7.22 \\
\hline October & 1.12 & 62.85 & 5.33 & 3.13 & 131.90 & 8.56 \\
\hline November & 1.01 & 56.34 & 4.78 & 2.09 & 91.28 & 7.78 \\
\hline December & 0.93 & 52.75 & 5.78 & 1.20 & 74.25 & 6.89 \\
\hline January & 0.89 & 50.78 & 5.78 & 0.99 & 64.44 & 5.89 \\
\hline February & 0.90 & 50.99 & 7.78 & 1.14 & 74.61 & 6.56 \\
\hline Mean & 1.49 & 81.80 & 6.95 & 2.01 & 123.63 & 7.49 \\
\hline $\mathrm{StD}$ & \pm 0.73 & \pm 42.85 & \pm 2.41 & \pm 0.98 & \pm 77.41 & \pm 2.04 \\
\hline
\end{tabular}



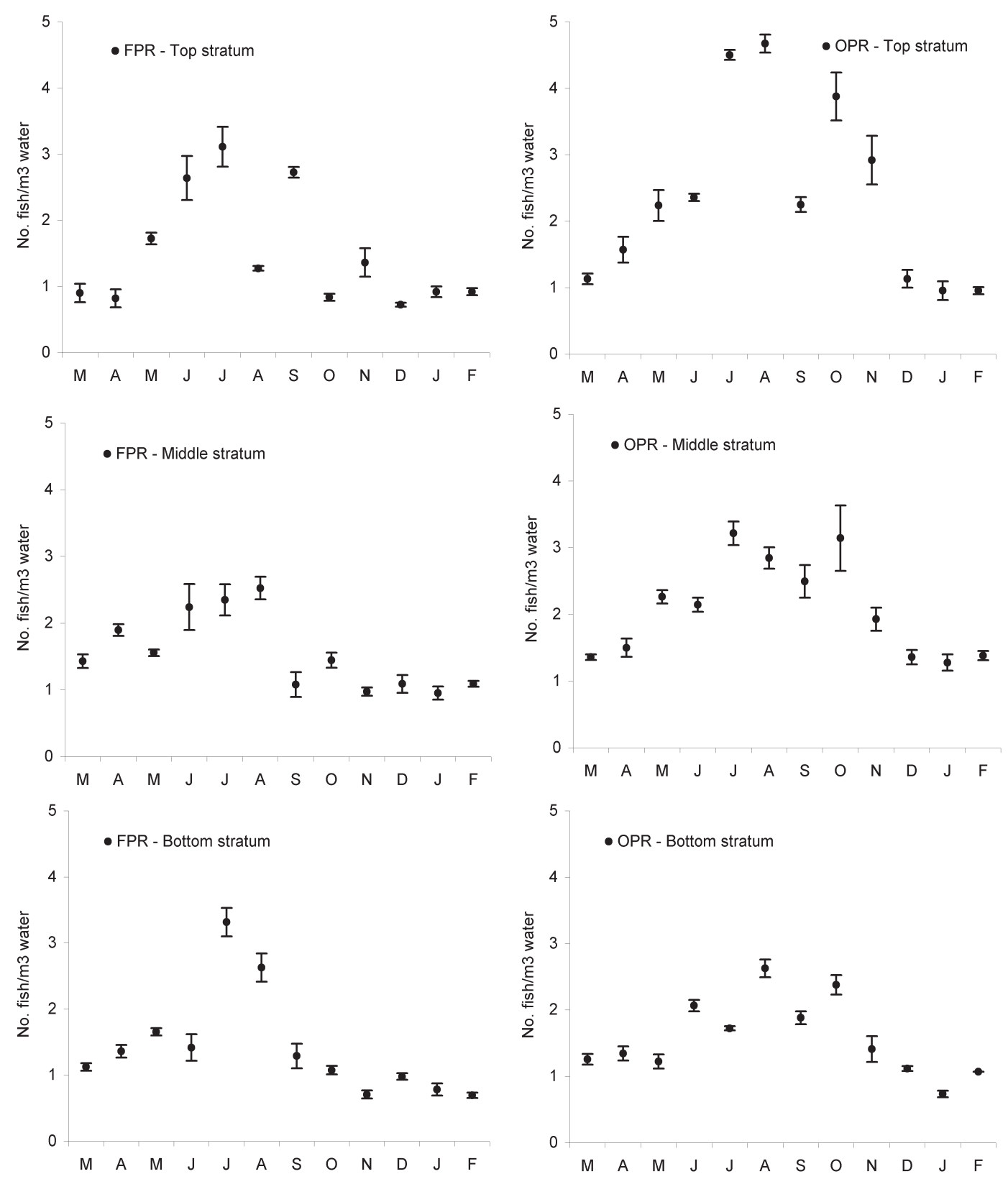

FIG. 5. - Mean fish density and standard deviation per stratum at the Faro protection reef (FPR) and the Olhão protection reef (OPR).

to $2.52 \mathrm{fish} / \mathrm{m}^{3}$ and from 1.28 to $3.22 \mathrm{fish} / \mathrm{m}^{3}$ at OPR. In the bottom stratum the lowest values recorded were 0.70 and $0.74 \mathrm{fish} / \mathrm{m}^{3}$ and the highest 3.32 and $2.63 \mathrm{fish} / \mathrm{m}^{3}$ at FPR and OPR respectively.

In terms of biomass density we found significant differences between the two artificial reefs (Table 4). The mean values found were 81.80 and 123.63 $\mathrm{g} / \mathrm{m}^{3}$ at FPR and OPR respectively (Table 5). The biomass variation showed a similar pattern on both artificial reefs, following that described above for the fish density. In terms of biomass density among the three strata, significant differences were found both within and between the artificial reefs, with generally higher values at OPR (Fig. 6, Table 4). In the top stratum the mean biomass density ranged from 21.48 to $189.48 \mathrm{~g} / \mathrm{m}^{3}$ and 33.88 and 159.72 $\mathrm{g} / \mathrm{m}^{3}$ at FPR and OPR respectively. The mean biomass density in the middle stratum ranged from 45.86 to $142.89 \mathrm{~g} / \mathrm{m}^{3}$ at FPR and from 56.97 to $231.58 \mathrm{~g} / \mathrm{m}^{3}$ at OPR. In the bottom stratum the lowest values recorded were 47.15 and $69.39 \mathrm{~g} / \mathrm{m}^{3}$ and the highest 182.92 and $349.89 \mathrm{~g} / \mathrm{m}^{3}$ at FPR and OPR respectively. 

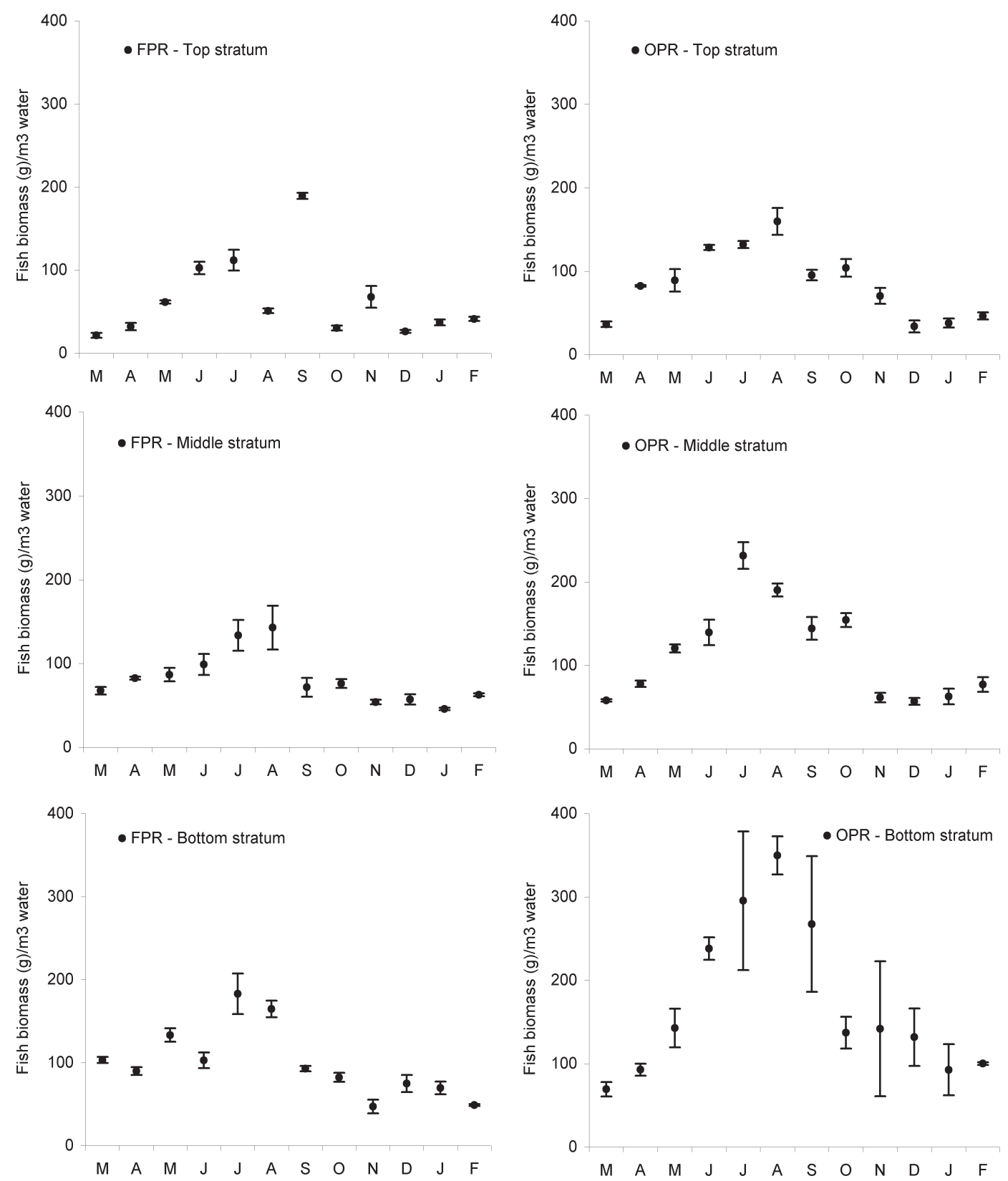

FIG. 6. - Mean biomass and standard deviation per stratum at the Faro protection reef (FPR) and the Olhão protection reef (OPR).

\section{DISCUSSION}

\section{Community composition}

Most species recorded on the artificial reefs of the Algarve waters are characteristic of the infralittoral and are readily found on rocky bottoms. The total number of species recorded was greater than that found by Bayle-Sempere et al. (1994) in the south-western Mediterranean (21 species) and by D'Anna et al. (1995) in Sicily (22 species), but lower than that found by Relini et al. (1994) in the northwestern Mediterranean (41 species) and Herrera et al. (2002) in the Canary Islands (53 species).

We would expect a more diversified community at FPR than at OPR, because that is the pattern observed along this coast. However, it seems that the OPR is like an "oasis" in which the species became aggregated, since this is the only hard structure in the vicinity. Several authors have suggested that species richness associated with artificial reefs may be related to the degree of isolation (Gascon and Miller, 1981; Walsh (1985); Bohnsack et al., 1991; Ody and Harmelin, 1994; Herrera et al., 
2002). On the other hand, the OPR location (closer to the main openings of the Ria Formosa lagoon), favours their colonisation by those specimens that cyclically migrate from the lagoon, namely juveniles of the Sparidae family. The differences in colonisation of the two reefs by the juvenile fish that cyclically migrate from the Ria Formosa was not evident comparing gill net catches (Santos and Monteiro, 1997, 1998; Santos et al., 1997), as the mesh size used (60 $\mathrm{mm}$ stretched mesh) was unable to catch the smaller fishes.

\section{Residence status and spatial occupation}

The resemblance of the two protection reefs in terms of residence status and spatial occupation was expected, since they have the same shape, size and volume and were colonised by essentially the same species of fish. As noted by Harmelin (1987), the concept of resident fish, as defined by the persistence of the fish assemblages, is difficult to apply, because it depends on the scale of observation considered (space and time) and on the efficiency of the observer. However, it is very useful, since it gives an idea of reef complexity and spatial heterogeneity, which determine the number of available niches.

As Harmelin (1987) postulated, greater space heterogeneity is responsible for higher proportions of resident species. The proportion of resident species on these artificial reefs is lower than that found by Bayle-Sempere et al. (1994) in Tabarca Island (SE of Spain), but similar to that recorded by Charbonnel (1990) and Ody (1987) in the NW Mediterranean coast of France. We considered the moray (Muraena helena), the conger (Conger conger) and the butterfly blenny (B. ocellaris) as resident species in spite of the fact that they were not observed frequently. According to Whitehead et al. (1986), the first two species have cryptic and nocturnal habits and despite the fact that we made three counts per stratum, their visual detection was low. Bayle-Sempere et al. (1994) adopted the same criteria in a similar study. Trisopterus luscus was also considered a resident. Despite a low mean percent occurrence, this species was particularly abundant on some reef groups but absent on others. We could not find any explanation for this. In the case of the blennies, they were not seen more often due to their behaviour and colour. Most blennies were found hidden in holes or between the macrobenthic epifauna and epiflora. Most of the resident species are sedentary, showing high site-fidelity and belonging to classes 3, 5 and 6, of the Harmelin (1987) classification.

According to Amanieu and Lassèrre (1982), ecological indices provide general information about community structure. The species richness indicates the capacity of reception. Since the total number of species found in the two systems was similar to that recorded by Santos et al. (1995) on the neighbouring natural reefs, we believe that these five-year old artificial reefs are close to or have already reached an equilibrium level. According to Bohnsack and Sutherland (1985), the equilibrium community structure is achieved within one to five years. However, the community structure could change in the future, depending on the succession of the other colonisers (benthic epifauna and epiflora).

\section{Mean species richness and mean species diversity}

Seasonal variation of fish communities, and thus of the mean number of species and species diversity, has been previously reported by several authors (Bohnsack and Sutherland, 1985; Relini et al., 1994; D’Anna et al., 1994, 1995; Fabi and Fiorentini, 1994; Bayle-Sempere et al., 1994; Relini et al., 2002). The monthly variation of these ecological indices is generally linked with water temperature and follows the seasonal pattern, with maximum values in summer and minimum values in winter. Thus, we expected both systems to show this pattern, but FPR did not. As shown in Figure 2, during the sampling period the sea surface water temperature followed a slightly different pattern off Faro. In fact, the water was unusually cold from August to October and slightly warm in March and February. FPR showed a greater intra-annual variation of the ecological indices than OPR, but it is not clear whether this was a result of the unusual water temperature pattern in the area or a consequence of the natural characteristics of this particular environment. The Faro area is characterised by the presence of natural reefs in the nearby shallower waters and is affected by the tidal currents, being exposed to an intensive hydrodynamic process which constantly re-suspends bottom sediments (e.g. particulate organic carbon and particulate organic nitrogen suspended/re-suspended in the water column at FPR are 2 times higher than those obtained at OPR). The comparison of the species richness between the two reefs showed very well the influence of the Ria Formosa lagoon at OPR, which is 
the nearest reef to the lagoon, especially in autumn when the juvenile specimens migrate from the lagoon to the coastal waters (Monteiro et al., 1987, 1990). Santos et al. (1995) showed that there were no differences between the mean species richness of FPR and a neighbouring natural reef. Thus, the differences found in the current study between FPR and OPR, are probably due to the influence of the lagoon at OPR.

\section{Fish and biomass densities}

The fish and biomass densities followed the usual annual variation in water temperature. D'Anna et al. (1995) in Sicily and Fabi and Fiorentini (1994) in the Adriatic Sea reported this pattern previously. The mean density of fish and biomass found on the artificial protection reefs of the Algarve waters was higher than those found by Ambrose and Swarbrick (1989) in southern California, Relini et al. (1994) in the northwestern Mediterranean and D'Anna et al. (1994, 1995) in Sicily. As stated before, these differences were not evident in previous studies that made use of gill net catch data (Santos and Monteiro, 1997, 1998; Santos et al., 1997).

In terms of the fish density per stratum, the values recorded at the top of the OPR were mainly due to the young-of-the-year that usually migrate from the Ria Formosa lagoon (e.g. Diplodus spp.). These migrations occur primarily in summer and late autumn (Monteiro et al., 1990) and were responsible for the main differences between the two artificial reefs in these periods. At FPR these small fish (9-11 $\mathrm{cm}$ ) do not occur in such high densities as at OPR. This is probably related to the distance from the main openings of the lagoon and the existence of other (natural) reefs in the FPR area. The Ria Formosa also contributes to the greater variation in fish density between strata. During our surveys we observed small shoals of young-of-the-year specimens, especially in the top stratum.

The mean biomass density increased from the top to the bottom of the reefs. This pattern is due to the fact that the larger animals prefer to hide on the bottom, while the smaller fish occur mainly in the upper stratum. However, it was not clear whether this behaviour was caused by the presence of the divers. Arriving at the reefs, we sometimes saw large fish swimming quickly to the bottom, where they would stay for a while or swim away. Because of this behaviour we always started our surveys by the lower stratum.
Although the two artificial reefs showed similar trends of intra-annual variation, both in terms of fish and biomass densities, differences between FPR and OPR occurred especially in July-August, which is the period of migration of juvenile fish from the Ria Formosa lagoon to the coastal waters (Monteiro et al., 1990). These results highlight the importance of the lagoon in the colonisation of the OPR. However, these differences may also be due to the isolation of the OPR (the "oasis" effect) and the existence of natural reefs in the Faro area, which favours the distribution of the fish assemblages in a wider area. On the other hand, the differences in substrate between the two sites apparently do not affect the species composition or their abundances.

As a general conclusion, these results show that similar artificial reefs (in terms of complexity and size) located not far from each other may aggregate different fish assemblages as a result of their isolation and the influence of both hydrological features (e.g. water temperature) and endogenous biological processes in the area (e.g. proximity of nursery grounds).

\section{ACKNOWLEDGEMENTS}

The authors would like to thank Prof. K. Erzini for reviewing the manuscript and Prof. M. Castro for helping with the statistical analysis. Thanks are due to O. Almeida and M.B. Gaspar for helping with the data collection, and to P. Lino for processing the figures.

\section{REFERENCES}

Amanieu, M. and G. Lassèrre. - 1982. Organisation et évolution des peuplements lagunaires. Oce. Act., Special No., Sept.: 201-213.

Ambrose, R.F. and S.L. Swarbrick. - 1989. Comparison of fish assemblages on artificial and natural reefs off the coast of southern California. Bull. Mar. Sci., 44(2): 718-733.

Ardizzone, G.D., M.F. Gravina and A. Belluscio. - 1989. Temporal development of epibenthic communities on artificial reefs in the central Mediterranean Sea. Bull. Mar. Sci., 44(2): 592-608.

Bayle-Sempere, J.T., A.A. Ramos-Esplá and J.A. Garcia-Charton. 1994. Intra-annual variability of an artificial reef fish assemblage in the marine reserve of Tabarca (Alicante, Spain, SW Mediterranean). Bull. Mar. Sci., 55(2-3): 824-835.

Bohnsack, J.A. and D.L. Sutherland. - 1985. Artificial reef research: a review with recommendations for future priorities. Bull. Mar. Sci., 37(1): 11-39.

Bohnsack, J.A. and S.P. Bannerot. - 1986. A stationary visual census technique for quantitatively assessing community structure of coral reef fishes. NOAA Tech. Rep. NMFS, 41: 1-15.

Bohnsack, J.A., D.L. Johnson, and R.F. Ambrose. - 1991. Ecology of artificial reefs habitats and fishes. In: W. Seaman Jr. and L. Sprague (eds.), Academic Press Inc., Artificial Habitats for Marine and Freshwater Fisheries, Chap. 3, pp. 61-107. San Diego, California, USA.

Borges, T.C., S. Olim and K. Erzini. - 2003. Weight-length rela- 
tionships for fish species discarded in commercial fisheries of the Algarve (southern Portugal). J. Appl. Ichtiol., 19: 394-396.

Charbonnel, E. - 1990. Les peuplements ichtyologiques des récifs artificiels dans le Département des Alpes-Maritimes (France). Bull. Soc. Zool. France, 115: 123-136.

D’Anna, G., F. Badalamenti, M. Gristina and C. Pipetone. - 1994. Influence of artificial reefs on coastal nekton assemblages of the Gulf of Castellamare (Northwest Sicily). Bull. Mar. Sci., 55(2-3): 418-433.

D’Anna, G., F. Badalamenti, R. Lipari, A. Cittitta and C. Pipetone. - 1995. Fish assemblage analysis by means of a visual census survey on an artificial reef and on natural areas in the Gulf of Castellamare (NW Sicily). In Jap. Int. Mar. Sci. Tec. Fed. (ed.) Proceedings of ECOSET'95, Vol. I: pp. 221-226. Tokyo, Japan.

Fabi G. and L. Fiorentini. - 1994. Comparison between an artificial reef and a control site in the Adriatic Sea: analysis of four years of monitoring. Bull. Mar. Sci., 55(2-3): 538-558.

Froese, R. and D. Pauly. (eds.) - 2003. FishBase. World Wide Web electronic publication. www.fishbase.org, version 12, November 2003.

Gascon, D., and R.A. Miller. - 1981. Colonization by near-shore fish on small artificial reefs in Barkley Sound, British Columbia. Can. J. Zool., 59: 1635-1646.

Gómez-Buckley, M. and R. Haroun. - 1994. Artificial reefs in the Spanish Coastal zone. Bull. Mar. Sci., 55(2-3), 1021-1028.

Harmelian-Vivien, M., J.G. Harmelin, C. Chauvet, C., Duval, R. Galzin., P. Lejeune, G. Barnabé, F. Blanc, R. Chevalier, L. Duclerc, G. Lassèrre. - 1985. Evaluation visuelle des peuplements et populations de poissons: problèmes et méthodes. Rev. Eco. Ter. Vie, 40: 467-539.

Harmelin, J.G. 1987. Structure et variabilité de l'ichtyofaune d'une zone rocheuse protégée en Méditerranée (Parc National de Port-Cros, France). P.S.Z.N.I. Mar. Ecol., 8:263-284.

Herrera, R., F. Espino, M. Garrido, and R. Haroun. - 2002. Observations on fish colonization and predation on two artificial reefs in the Canary Islands. ICES J. Mar. Sci., 59: S69-S73.

Jensen, A.C. - 2002. Artificial reefs of Europe: perspective and future. ICES J. Mar. Sci., 59: S3-S13.

Jones, R.S. and Thompson M.J. - 1978. Comparisons of Florida reef fish assemblages using a rapid visual technique. Bull. Mar. Sci., 28: 159-172.

Monteiro, C.C., T. Lam Hoai and G. Lassèrre. - 1987. Distribution chronologique des poissons dans deux stations de la lagune Ria Formosa (Portugal). Oceanol. Acta, 10(3): 359-371.

Monteiro, C.C., G. Lasserre, and T. Lam Hoi. - 1990. Organisation spatiale des communautés ichtyologiques de la Lagune Ria Formosa (Portugal). Oceanol. Acta, 13(1): 79-96.

Moreno I., I. Roca, O. Reñones, J. Coll and M. Salamanca. - 1994. Artificial reef program in Balearic waters (western Mediterranean). Bull. Mar. Sci., 55(2-3), 667-671.

Neter J., W. Wasserman and M.H. Kutner. - 1983. Applied linear regression models. Richard D. Irwin, Inc.

Ody, D. - 1987. Les peuplements des récifs artificiels de Provence (France, Méditerranée Nord Occidentale). Thèse $3^{\mathrm{ème}}$ cycle, Univ. Aix-Marseille II.

Ody, D., and J.G. Harmelin. - 1994. Influence de l'architecture et de la localisation des récifs artificiels sur leurs peuplements de poissons en Méditerranée. Cybium, 18(1): 14.

Relini, M., G. Torchia and G. Relini. - 1994. Seasonal variation of fish assemblages in the Loano artificial reef (Ligurian Sea Northwestern Mediterranean). Bull. Mar. Sci., 55(2-3): 401-417.

Relini, G., M. Relini, G. Torchia, and G. Palandri. - 2002. Ten years of censuses of fish fauna on the Loano artificial reef. ICES J. Mar. Sci., 59: S132-S137.

Santos, M.N. - 1997. Ichthyofauna of the artificial reefs of the Algarve coast. Exploitation strategies and management of local fisheries. Ph.D thesis, Univ. Algarve.

Santos, M.N., C.C. Monteiro and K. Erzini. - 1995. Comparison of natural and artificial reef fish assemblages in Algarve waters (south Portugal). In: Jap. Int. Mar. Sci. Tec. Fed. (ed.) Proceedings of ECOSET'95, Vol. I: pp. 210-214. Tokyo, Japan.

Santos, M.N., C.C. Monteiro and G. Lassèrre G. - 1996. Relations habitat richesse spécifique des poissons de deux récifs artificiels sur le littoral de la Ria Formosa (Portugal). Oce. Act, 19(1): 89-97.

Santos, M.N., and C.C. Monteiro. - 1997. Olhão artificial reef system (south Portugal): fish assemblages and fishing yield. Fish. Res., 30: 33-41.

Santos, M.N., C.C. Monteiro and G. Lassèrre G. - 1997. A fouryear overview of the fish assemblages and yield on two artificial reef systems off Algarve (south Portugal). In: L.E. Hawkins and S. Hutchinson, with A.C. Jensen, J.A. Williams and M. Sheader (eds.). The responses of marine organisms to their environment, pp. 345-352. Univ. Southampton.

Santos, M.N., and C.C. Monteiro. - 1998. Comparison of the catch and fishing yield from an artificial reef system and neighbouring areas off Faro (south Portugal). Fish. Res., 39: 55-65.

Santos, M.N. and C.C. Monteiro. - 2001. The Portuguese experience on artificial reefs: past and future. In: J. Coimbra (ed.), Modern aquaculture in the coastal zone: lessons and opportunities. NATO Science Series, Serie A: Life Sciences, Vol. 314 pp. 281-294.

Santos, M.N., C.C. Monteiro and M.B. Gaspar. - 2002a. Diurnal variations in the fish assemblage at an artificial reef. ICES J. Mar. Sci., 59: S32-S35.

Santos, M.N., M.B. Gaspar, P. Vasconcelos and C.C. Monteiro. 2002b. Weight-length relationships for 50 selected fish species of the Algarve coast (southern Portugal). Fish. Res., 59(1-2): 289-295.

SAS Institute Inc. - 1985. SAS user's guide: statistics. Version $5^{\text {th }}$ edition. SAS Institute Inc., Cary, North Carolina.

Scherrer, B., 1984. Biostatistic. Gaëtan Morin (ed.), Canada, Quebec, Chicoutimi.

Spanier, E., M. Tom, S. Pisanty and G. Almong. - 1989. Artificial habitat for fisheries in the south-eastern Mediterranean: a model for low productive marine environments. Bull. Mar. Sci., 44(2): 1070.

Statsoft Inc. - 1993. STATISTICA. Vol. I, II and III.

Stone, R.B., J.M. McGurrin, L.M. Sprague and W. Seaman Jr. 1991. Artificial Habitats of the World: Synopsis and Major Trends. In: W. Seaman Jr. and L. Sprague (eds.), Academic Press Inc., Artificial Habitats for Marine and Freshwater Fisheries, Chap. 2, pp. 31-60. San Diego, California, USA.

Thompson, M.J. and T.W. Schmidt. 1977. Validation of the species/time random count technique for sampling fish assemblages. Proc. $3^{\text {th }}$ Int. Coral Reef Symp., Miami, Florida, 1: 283-288.

Walsh, W.J. - 1985. Reef fish community dynamics on small artificial reefs: the influence of isolation, habitat structure, and biogeography. Bull. Mar. Sci., 36: 357-376.

Whitehead, P.J.P., M.-L. Bauchot, J.-C. Hureau, J. Nielsen and E. Tortonese. (eds.). - 1986. Fishes of the North-eastern Atlantic and the Mediterranean. UNESCO (Vols. I, II, III), Paris.

Scient. ed.: P. Abelló 